International Journal of Arts and Humanities Studies (IJAHS)

ISSN: $2754-4311$

DOI: $10.32996 /$ ijahs

Journal Homepage: www.al-kindipublisher.com/index.php/ijahs

\title{
Orientalism on Trial: Rethinking The Post-colonial Project in The East
}

\author{
Ousama Bziker \\ Ibn Tofail University, School of Humanities, Kenitra, Morocco \\ $\square$ Corresponding Author: Ousama Bziker, E-mail: ousama.bziker@uit.ac.ma
}

\begin{abstract}
ARTICLE INFO
Received: 15 September 2021

Accepted: 11 October 2021

Published: 25 October 2021

DOI: 10.32996/ijahs.2021.1.1.5

\section{KEYWORDS}

Orientalism, postcolonialism, the post-colonial project, imperialism, dominance, knowledge, power,

\section{ABSTRACT}

This article explores the perplexities revolving in the vicinity of Orientalism. It tries to discern, dissect, and (re)view Orientalism and its role in shaping today's world, more importantly, the binomial ambivalence of the West versus East connection. Said's work, Orientalism, is going to be the locus of this article. In his book, the author tries to describe how the West perceives and represents the East. Through the author's journey in the U.S., where he spent most of his life, he noticed that the West considers the East a one homogenous and static body. Edward Said's stance on the separation of the world into two entities and the postcolonial project did not go unnoticed. In this article, the author's work is analyzed in relation to his critics such as Ahmed Aijaz, Bernard Lewis, Samuel Huntington, and others.
\end{abstract} mis-representation, Eurocentric, Arabo-Islamic.

\section{Introduction}

Edward Said's (1978) Orientalism came as a reaction to the misconceptions the Western orientalists have had on the East. This book attempts to diminish, if not eradicate, the image the West has had on the Orient. More than that, in his book, Said tries to unravel the distinction between 'rational West' and 'irrational East', as this has opened the door for Westerners to dominate the Orient. Despite the book's weight, it has risen vehemently, sometimes vicious, preponderant criticism from different scholars. This article will try to analyze how 'Orientalism' is used as a window through which the 'West' (re)-presents the 'Orient' based on preconceived archetypes that picture Arab/Amazigh culture as one similar society. The latter representation results in producing, as it were, 'Western' imperial dominance over the 'East'.

\section{Discerning and Dissecting Orientalism}

Orientalism is an attempt to dissect texts that are usually taken for granted. In his book, Said tries to make a distinction between ideas, images, and representations. He argues that the West is influenced by European ideas and preconceptions, to the extent they could not take a neutral stance while dealing with topics related to the Orient (Said, 1978). Said emphasizes the idea that the Orient classifies their texts as inferior and that they need to resort to European authority and guidance. He stresses that orientalists see the Orient as stagnant and unchanging. It could only achieve potential growth provided they become 'Westernized' (Said, 1978).

As a reaction to the West's rigorous commitment to study the East, Said comes up with the idea that Orientalism is a form of thought that can be used to dissolve and break down Western values and how they see the East (Said, 1978). The misconceptions the West has on the East, for instance writing books on the East without actually being in the East, can only expose the West's stand. Said posits that the West used a one-size-fits-all approach to represent the Orient. He claims that it was a "subtle and persistent Eurocentric prejudice against Arabo-Islamic peoples and their culture" (Said, 1978). He contends that the misrepresentation of Asia, the Middle East, and North Africa in Western culture has fostered the justification for the West's colonial and imperial power. Said contends that through the appropriation and translation of the Orient's history and languages, the West

Copyright: (c) 2021 the Author(s). This article is an open access article distributed under the terms and conditions of the Creative Commons Attribution (CC-BY) 4.0 license (https://creativecommons.org/licenses/by/4.0/). Published by Al-Kindi Centre for Research and Development, London, United Kingdom. 
was able to conquer them politically. Kim states that white authors cannot give an accurate representation of Asians, "AngloAmerican literature does not tell us about Asians. It tells us about Anglos' opinions of themselves, in relation to their opinions of Asians" (Kim, 1982). The West has written Asia's history and constructed its modern identities from a point of view that puts Europe in the center and places the Orient in the periphery.

World-Systems Theory, as discussed by Immanuel Wallerstein, is a system that puts artificial boundaries between core states, semiperipheral, and peripheral (Wallerstein, 1989). In this regard, Said argues that Orientalism is about two opposing entities; two worlds. He ascertains that Europeans divided the world into the East and the West or the civilized and the uncivilized or what Said refers to as 'othering'; 'ours' versus 'theirs'. The West was ranked as the supreme race and that it was their responsibility to 'civilize' the 'uncivilized'. Said posits that the West misrepresents the Orient, he said, "They cannot represent themselves, they must be represented". According to Michel Foucault, power lies everywhere and in all intellectual fields. "On Foucault's account, the relation of power and knowledge is far closer than in the familiar Baconian engineering model, for which 'knowledge is power' means that knowledge is an instrument of power, although the two exist quite independently. Foucault's point is rather than, at least for the study of human beings, the goals of power and the goals of knowledge cannot be separated; in knowing we control (Foucault, 1977)". Knowledge is power - that is brought by Foucault - goes in congruence with Said's groundbreaking work "Orientalism" that pins down how much knowledge the West has gathered to control the East. Said states that "The relationship between Occident and Orient is a relationship of power, of dominion, of varying degrees of a complex hegemony..." (Said, 1978). He asserts that the "knowledge of subject races or Orientals is what makes their management easy and profitable; knowledge gives power, more power requires more knowledge, and so on in an increasingly profitable dialectic of information and control (Said, 1978: 36)".

\section{The Critique of Said's Orientalism}

Such a grand work as that of Said's, without doubt, did not evade ferocious criticism laid by other renowned authors. Said starts his book with a thesis that, "Orientalism derives from a particular closeness experienced between Britain and France and the Orient, which until the nineteenth century had really meant only India and the Bible lands". Bernard Lewis, an American-British historian, argues that Said's decisions are arbitrary and that he scaled the Orient down to the Middle East and excluded the Arab/Amazigh World. Then, Lewis stresses that Said strips the Orient from its historical and philological contexts by excluding Turkish and Persian, and Semitic studies (Lewis, 1982). Also, Lewis states, "The Germans are not the only scholars omitted from Mr. Said's survey. More remarkably, he has also omitted the Russians. Their contribution, though considerable, is less than that of the Germans or even of the British and the French" (Ibid). Lewis thinks that Said overlooked - or did not acknowledge - the major contribution of Westerners during the Enlightenment and Victorian age (Ibid). It is important to note that Said did not highlight why Orientalist studies did not explain the cause of imperialism (Ibid). Another prominent figure in this realm, or I should say among the first critics, Ahmed Aijaz who argued that the chronology of Orientalism developed by Said was not accurate enough as a point of reference to identify the emergence of Orientalism as a discourse. Ahmed stormed Said with criticism on this point and he argues that Said's approach to validating his argument is a sloppy attempt from someone well-versed in the intellectual arena. Ahmed questioned the starting point of Orientalism raised by Said that gave rise to questions like: Why has Orientalism started exactly during the late eighteenth century and not before? (Ahmed, 2000)

Having a dubious stance that baffles the mind, one can only assume, or as Nietzsche puts it, "there are no facts, but only interpretations" (Nietzsche, 1886). Although Ahmed raised an interesting point, one cannot ignore the fact that there is some truth to Said's argument. Certainly, Edward Said did not invent Orientalism nor did he pin it down when it had already started, but in fact, what he did is that he labeled it as "Orientalism". We can all agree that Orientalism dates back to no absolute point of reference in history, but we can agree on one thing that this discourse started before it was labeled by Said. One can draw a conclusion that Said was not talking about when Orientalism started but when he labeled it, or when he pinned it down. Sadik follows the same path of criticism as that of Aijaz. He argues that Said has changed the direction that goes from colonialism to Orientalism, which means that this phenomenon goes from political economy to cultural history. Sadik argues that Said reproduces the discourse of the West (Sadik, 1981).

One cannot talk about Edward Said without mentioning his rival Samuel Huntington and their debate over Orientalism. Huntington argues, "Over the centuries, however, differences among civilizations have generated the most prolonged and the most violent conflicts" (Huntington, 1993). He says that different religions and cultures are the sources of many clashes among civilizations. As time goes on, people will look for their identity and focus more on the differences rather than increasing commonalities. However, Said fiercely rebuffs this and he says, "Downright ignorance is involved in presuming to speak for a whole religion or civilization"(Said, 2001). He also states, "trying to plow or divide them with barriers is futile (lbid)". Said, in fact, was not the only one who disagrees with Huntington, Arnold Toynbee, a British historian, argues that to unify the world one has to start with the assumption that all histories belong to everyone, and that to separate Western and non-Western is no longer valid. He states: 
"Our own descendants are not going to be just Western, like ourselves. They are going to be heirs of Confucius and Lao-Tse [sic] as well as Socrates, Plato, and Plotinus; heirs of Gautama Buddha as well as Deutero-Isaiah and Jesus Christ; heirs of Zarathustra and Muhammed as well as Elijah...; heirs of Shankara and Ramanuja as well as Clement and Origen;...and heirs... of Lenin and Gandhi and Sun Yat-sen as well as Cromwell and George Washington and Mazzini (Toynbee 1948, 90)."

Ostensibly, he claims that syncretic religion is achievable as well as merging previous insights with novel ones; as a result, political conflict is going to be an issue of the past (Toynbee, 1956).

\section{Conclusion}

We can extrapolate that since history is often written by the winners, it feels safe to say that one's legacy can only be written by its authors and not people who haven't been through their cultural, political, and economic changes. All in all, Edward Said seems to have drawn most of the patterns that discern Orientalism in our modern world. He describes and analyses the source of misconceptions and misrepresentations the West has on the Orient through Western lenses. Orientalism has always existed and will not cease to exist if we continue to ignore it as a discourse that the West uses to justify its economic exploitation, cultural imposition, and political domination of the Orient. Edward Said was against the idea of drawing boundaries and separating the West from the East, this very separation is the source of Western domination. Although Orientalism has received heavy criticism, it is nothing but an indication that Said's work is a sound argument.

\section{References}

[1] Aschheim, S. E. (1994). The Nietzsche Legacy in Germany: 1890-1990 (Vol. 2). Univ of California Press.

[2] Al-Azm, S. J. (1981). Orientalism and Orientalism in reverse. Khamsin, 8(1981), 5-26.

[3] Kim, E. H. (1982). Asian American literature, an introduction to the writings and their social context. Temple University Press.

[4] Lewis, B. (1982). The question of Orientalism.

[5] McMichael, P. (1990). Incorporating comparison within a world-historical perspective: An alternative comparative method. American sociological review, 385-397.

[6] NAMBIAR, R. Re-Negotiating Orientalism through the Prism of Edward Said vs. Aijaz Ahmed debate on Marx, Europe and India (East).

[7] Pratt, M. (1978). Discipline and Punish—the Birth of the Prison.

[8] Said, E. W. (2003). Orientalism.[1978] London. Henley Routledge.

[9] Said, E. W. (2001). The clash of ignorance'The Nation. New York: oct, 273(12).

[10] Shulman, S. (1998). Huntington, Samuel P. The Clash of Civilizations and the Remaking of World Order. JOURNAL OF POLITICS, 60, 305-306.

[11] Toynbee, A. J. (1948). Civilization on trial. 